\title{
IDENTIFIKASI Salmonella sp PADA AIR RENDAMAN SPONS CUCI PIRING BEKAS YANG DIRENDAM SELAMA 3 HARI
}

\author{
Anita ${ }^{1)}$, Muh. Rifo Rianto ${ }^{1)}$ Dewi Arisanti ${ }^{1)}$, Anang H Radjak ${ }^{1)}$ \\ ${ }^{1)}$ Teknologi Laboratorium Medis, Politeknik Kesehatan Muhammadiyah Makassar \\ Alamat Korespondensi: anitadinar1983@gmail.com
}

\section{Artikel info:}

Received: Desember 2021

Revised: Desember 2021

Accepted: Desember 2021

Publish: Desember 2021

\begin{abstract}
Abstrak
Spons cuci piring adalah alat yang sering digunakan sebagian besar masyarakat untuk membersihkan peralatan makan, namun tidak dicantumkan cara penggunaannya sehingga mengurangi pengetahuan konsumen dalam menjaga kebersihan serta kondisi spons yang dipakai. Spons cuci piring 200.000 kali lebih kotor dibandingkan dudukan toilet, sehingga pemakaian lebih dari 3 hari dan didiamkan dalam keadaan lembab dapat mendukung pertumbuhan bakteri diantaranya Salmonella sp. Bakteri Salmonella sp bersifat gram negatif, tidak membentuk spora, fakultatif anaerobik, berbentuk motil dan batang. Salmonella adalah bakteri mesofilik, dapat hidup pada kisaran suhu 5-46 ${ }^{\circ}$, dan suhu pertumbuhan terbaik adalah $35-37^{\circ}$ C. Penelitian ini bertujuan untuk mengetahui apakah Salmonella sp terdapat pada spons cuci piring bekas yang direndam selama 3 hari. Metode penelitian ini dilakukan terhadap 5 sampel spons cuci piring bekas dengan cara eksperimen dan dilakukan dengan cara uji kultur pada media. Hasil penelitian ini menunjukkan bahwa semua sampel spons positif adanya kontaminasi bakteri Salmonella sp. Sehingga dapat disimpulkan penelitian pada identifikasi Salmonella sp pada spons cuci piring bekas yang direndam selama 3 Hari ditemukan adanya bakteri Salmonella sp.
\end{abstract}

Kata Kunci: Spons cuci piring, Salmonella sp.

\begin{abstract}
Dishwashing sponge is a tool that is often used by most people to clean cutlery, but it is not stated how to use it so that it reduces consumer knowledge in maintaining cleanliness and the condition of the sponge used. Dishwashing sponges are 200,000 times dirtier than a toilet seat, so using more than 3 days and left in a damp state can support the growth of bacteria including Salmonella sp. Salmonella sp bacteria are gram negative, do not form spores, facultative anaerobic, motile and rod-shaped. Salmonella is a mesophilic bacterium, can live in a temperature range of $5-46^{\circ} \mathrm{C}$, and the best growth temperature is $35-37^{\circ} \mathrm{C}$. This study aims to determine whether Salmonella $s p$ is present in used dishwashing sponges that have been soaked for 3 days. This research method was carried out on 5 samples of used dishwashing sponges by experiment and carried out by means of a culture test on the media. The results of this study indicate that all sponge samples were positive for Salmonella sp. So, it can be concluded that research on the identification of Salmonella sp in used dishwashing sponges soaked for 3 days found the presence of Salmonella sp.
\end{abstract}

Keywords: Dishwashing sponge, Salmonella sp 


\section{PENDAHULUAN}

Kebersihan peralatan makan merupakan aspek penting untuk melihat kualitas makanan atau minuman. Kotornya peralatan makan akan mendukung pertumbuhan organisme yang tertinggal dalam mencemari makanan. Makanan bisa terkontaminasi organisme lewat peralatan makan yang kurang bersih dalam pencucian (Tumerlap, H.J. 2011).

Spons cuci piring salah satu alat yang sering digunakan sebagian besar masyarakat di Indonesia. Macam-macam jenis dan merek spons cuci piring pun banyak beredar di masyarakat. Spons cuci piring yang diperjualbelikan pada masyarakat sebagian besar tidak dicantumkan cara penggunaannya. Dengan adanya label cara penggunaan spons ini, berguna dalam memberikan informasi yang harus diketahui oleh konsumen agar tetap menjaga kebersihan (Kalem, R.S et al. 2019).

Sisa makanan yang ada pada spons dapat mendukung pertumbuhan bakteri, spons cuci piring 200.000 kali lebih kotor dibandingkan dudukan toilet, sehingga apabila pemakaian lebih dari 3 hari dan dalam keadaan lembab rentan akan tumbuh bakteri (Gaffar, S. et al. 2014). Perlu diketahui bahwa spons cuci piring yang sering digunakan sehari-hari oleh masyarakat Indonesia merupakan sarang bakteri. Bermacam-macam bakteri yang mengkontaminasi spons dapat menyebabkan penyakit salah satunya Salmonella sp. Bakteri tersebut dapat mengkontaminasi peralatan dapur lainnya bila dicuci dengan mengguunakan spons yang sama (Jannah, R. 2018). Berdasarkan penelitian yang telah dilakukan oleh Gaffar et all (2014) menggunakan metode PCR-RFLP di laporkan terdapat bakteri yang hidup pada spons basah yaitu Escherichia coli. Penelitian ini belum pernah terdapat kasus di Indonesia terkait keberadaan bakteri Salmonella sp pada spons cuci piring.

Oleh karena itu penulis tertarik untuk melakukan identifikasi bakteri Salmonella $s p$ pada spons cuci piring yang direndam selama 3 hari (Supriani, 2019).

\section{METODE PENELITIAN}

Jenis penelitian yang digunakan dalam penelitian ini adalah metode deskriptif yang bersifat eksperimen secara kualitatif untuk mengidentifikasi bakteri Salmonella $s p$ pada spons cuci piring yang direndam selama 3 hari. Pengambilan sampel sebanyak 5 spons cuci piring yang direndam selama 3 hari. Teknik pengambilan sampel adalah purposive sampling dengan kriteria sampel spons cuci piring yang telah digunakan. Penelitian dilaksanakan di Laboratorium Bakteriologi Program Studi Teknologi Laboratorium Medis Politeknik Kesehatan Muhammadiyah Makassar. Penelitian ini dilakukan pada tanggal 1-5 Juli 2021.

Alat yang digunakan dalam penelitian ini adalah inkubator, timbangan analitik, autoklaf, lampu bunsen, ose, nald, labu erlenmeyer, rak tabung, tabung reaksi, cawan petri, pipet volume, batang pengaduk, korek api, tabung durham, tissue dan label. Bahan yang digunakan dalam penelitian ini adalah aquadest steril, spons cuci piring, BHIB, Methyl Red, Alfanaftol, $\mathrm{KOH} 40 \%$, Salmonella Shigella Agar (SSA), Glukosa, Laktosa, Sukrosa, Sulfur Indol Motility (SIM), Methyl Red Voges-Proskauer (MR-VP), Simon Citrat Agar (SCA), Triple Sugar Iron Agar (TSIA).

\section{HASIL DAN PEMBAHASAN}

Berdasarkan hasil penelitian yang telah dilakukan pada tanggal 1-5 juli 2021 untuk mengidentifikasi Salmonella $s p$ pada spons cuci piring bekas yang direndam selama 3 hari yang telah dilaksanakan di Laboratorium Bakteriologi Program Studi DIII Teknologi Laboratorium Medis Politeknik Kesehatan Muhammadiyah Makassar diperoleh hasil sebagai berikut: 
Tabel 1. Tabel pengamatan spons cuci piring pada media BHIB dan media SSA

\begin{tabular}{|c|c|c|c|}
\hline $\begin{array}{c}\text { Kode } \\
\text { Sampel }\end{array}$ & $\begin{array}{l}\text { Media } \\
\text { BHIB }\end{array}$ & $\begin{array}{c}\text { Ciri-ciri Koloni } \\
\text { pada } \\
\text { Media SSA }\end{array}$ & Hasil \\
\hline A & $\begin{array}{l}\text { Terjadi } \\
\text { kekeruhan }\end{array}$ & $\begin{array}{l}\text { Koloni halus, } \\
\text { dan berwarna } \\
\text { hitam }\end{array}$ & + \\
\hline B & $\begin{array}{l}\text { Terjadi } \\
\text { kekeruhan }\end{array}$ & $\begin{array}{l}\text { Koloni halus, } \\
\text { dan berwarna } \\
\text { hitam }\end{array}$ & + \\
\hline $\mathrm{C}$ & $\begin{array}{l}\text { Terjadi } \\
\text { kekeruhan }\end{array}$ & $\begin{array}{l}\text { Koloni halus, } \\
\text { dan berwarna } \\
\text { hitam }\end{array}$ & + \\
\hline D & $\begin{array}{l}\text { Terjadi } \\
\text { kekeruhan }\end{array}$ & $\begin{array}{l}\text { Koloni halus, } \\
\text { dan berwarna } \\
\text { hitam }\end{array}$ & + \\
\hline $\mathrm{E}$ & $\begin{array}{l}\text { Terjadi } \\
\text { kekeruhan }\end{array}$ & $\begin{array}{l}\text { Koloni halus, } \\
\text { dan berwarna } \\
\text { hitam }\end{array}$ & + \\
\hline
\end{tabular}

Sumber: Data Primer 2021

Berdasarkan hasil pengamatan tabel 1 di atas ditunjukan bahwa sampel spons cuci piring yang direndam selama 3 hari yang telah ditanam pada media BHIB terjadi pertumbuhan bakteri yang ditandai dengan adanya kekeruhan dan pada media SSA diperoleh hasil dengan ciri-ciri koloni dapat dilihat pada tabel 2.

Tabel 2. Hasil Pengamatan Mikroskop pada Pewarnaan Gram

\begin{tabular}{|c|c|c|c|}
\hline \multirow{2}{*}{$\begin{array}{c}\text { Kode } \\
\text { sampel }\end{array}$} & \multicolumn{3}{|c|}{ Hasil Pengamatan } \\
\hline & Bentuk & Morfologi & $\begin{array}{c}\text { Keterangan } \\
\text { gambar }\end{array}$ \\
\hline A & Basil & $\begin{array}{l}\text { Warna } \\
\text { merah }\end{array}$ & $\begin{array}{c}\text { Gram negatif } \\
(-)\end{array}$ \\
\hline B & Basil & $\begin{array}{l}\text { Warna } \\
\text { merah }\end{array}$ & $\begin{array}{c}\text { Gram negatif } \\
(-)\end{array}$ \\
\hline $\mathrm{C}$ & Basil & $\begin{array}{l}\text { Warna } \\
\text { merah }\end{array}$ & $\begin{array}{c}\text { Gram negatif } \\
(-)\end{array}$ \\
\hline $\mathrm{D}$ & Basil & $\begin{array}{l}\text { Warna } \\
\text { merah }\end{array}$ & $\begin{array}{c}\text { Gram negatif } \\
(-)\end{array}$ \\
\hline $\mathrm{E}$ & Basil & $\begin{array}{l}\text { Warna } \\
\text { merah }\end{array}$ & $\begin{array}{c}\text { Gram negatif } \\
(-)\end{array}$ \\
\hline
\end{tabular}

Sumber: Data primer 2021

Berdasarkan hasil pengamatan pada tabel 3 ditunjukan bahwa semua sampel spons cuci piring bekas yang direndam selama 3 hari pada pewarnaan gram diperoleh bentuk bakteri basil, berwarna merah, dan bersifat gram negatif (-).

Tabel 3. Hasil pengamatan pada media uji biokimia dari media selektif

\begin{tabular}{|c|c|c|c|c|c|c|c|c|c|c|c|c|}
\hline \multirow{2}{*}{$\begin{array}{c}\text { Kode } \\
\text { Sampel }\end{array}$} & \multicolumn{4}{|c|}{ Media TSIA } & \multirow[t]{2}{*}{ SIM } & \multirow[t]{2}{*}{ SCA } & \multirow{2}{*}{$\begin{array}{l}\mathbf{M} \\
\mathbf{R}\end{array}$} & \multirow{2}{*}{$\begin{array}{l}\mathbf{V} \\
\mathbf{P}\end{array}$} & \multicolumn{3}{|c|}{$\begin{array}{c}\text { Media Gula- } \\
\text { Gula }\end{array}$} & \multirow[t]{2}{*}{ Hasil } \\
\hline & Lereng & Dasar & Gas & $\mathrm{H}_{2} \mathrm{~S}$ & & & & & Glu & Suk & Lak & \\
\hline $\mathrm{A}$ & Asam & Asam & - & + & +-+ & + & + & - & + & + & + & Salmonella sp \\
\hline B & Asam & Asam & - & + & +-+ & + & + & - & + & + & + & Salmonella $s p$ \\
\hline $\mathrm{C}$ & Asam & Asam & - & - & +-+ & + & + & - & + & + & + & Salmonella sp \\
\hline $\mathrm{D}$ & Asam & Asam & - & + & +-+ & + & + & - & + & + & + & Salmonella $s p$ \\
\hline $\mathrm{E}$ & Asam & Asam & + & + & +-+ & + & + & - & + & + & + & Salmonella $s p$ \\
\hline
\end{tabular}

Sumber: Data primer 2021

Dalam proses identifikasi terhadap sampel penelitian ini diawali dengan pengambilan sampel spons cuci piring pada anak-anak kost yang dilakukan secara simple random sampling, kemudian sampel yang telah dikumpulkan didiamkan selama 3 hari dan dilakukan kontrol secara makroskopik. Setelah 3 hari dilakukan uji laboratorium.

Hasil kontrol di hari pertama menunjukan sampel spons cuci piring belum mengalami perubahan baik dari segi warna air, bau, serta kondisi spons. Sedangkan kontrol pada hari kedua dan ketiga telah mengalami perubahan tekstur sampel yang mulai lunak, kondisi sampel yang sudah mengeluarkan bau yang tidak sedap, dan air bekas rendaman yang sudah keruh.

Berdasarkan pengamatan yang telah dilakukan di hari pertama yang ditanam pada media Brain Heart Infussion Broth (BHIB), media berfungsi 
sebagai media pemupuk untuk mengoptimalkan pertumbuhan bakteri. Dari semua sampel, hasil yang diperoleh adalah positif ditemukan adanya pertumbuhan bakteri dengan ditandai terjadinya kekeruhan pada media.

Kemudian pada hari kedua diinokulasi pada media Salmonella Shigella Agar (SSA) media ini mengandung garam empedu dan brilian green untuk menghambat pertumbuhan bakteri gram positif dan menekan pertumbuhan basil patogen non enteric. Hasil yang didapatkan adalah koloni halus, dan berwarna hitam. Bakteri Salmonella sp mampu menghasilkan $\mathrm{H}_{2} \mathrm{~S}$ sehingga bakteri menunjukkan adanya penguraian asam amino yang mengandung sulfur. Untuk mengkonfirmasi hasil yang telah didapatkan maka dilakukan uji lanjutan pada biokimia.

Pada hari ketiga dari media SSA dilakukan pewarnaan gram di peroleh hasil dengan bentuk basil, susunan monobasil, berwarna merah yang menandakan bakteri tersebut bersifat gram negatif (-). Pada media TSIA hasil yang di peroleh untuk sampel A, B, C, D, $\mathrm{E}$, pada lereng dan dasar bersifat asam (kuning) karena bakteri mampu memfermentasikan glukosa, laktosa atau sukrosa, Gas negatif (-) pada sampel A, B, C, dan D karena tidak adanya pecahan pada media,sedangkan pada sampel E Gas positif (-) ditandai dengan adanya pecahan pada media.

Pada sampel $\mathrm{C} \quad \mathrm{H}_{2} \mathrm{~S}$ negatif (-) karena bakteri tidak mampu mendesulfurasikan asam amino ditandai dengan tidak timbulnya warna hitam pada bekas tusukan,sedangkan pada media A,B,D dan E H2S positif (+) menandakan bakteri mampu mendesulfurkan asam amino ditandai dengan timbulnya warna hitam pada bekas tusukan.

Pada media Simons Citrat Agar (SCA) semua sampel posistif (+) menandakan bakteri mampu tumbuh dengan menggunakan sitrat sebagai sumber karbon, hal ini ditandai dengan terjadinya perubahan warna dari warna hijau menjadi warna biru. Pada media Sulfur Indol Motility (SIM) yakni sulfur posistif (+) dikarenakan bakteri mampu memproduksi sulfida hal ini ditandai dengan adanya warna hitam pada bekas tusukan, Indol negatif (-) karena hal ini menandakan bahwa bakteri tersebut tidak menggunakan triptofan sebagai sumber energinya sehingga bakteri tersebut tidak mampu menghasilkan indol dengan ditandai pada media tidak timbul cincin merah dan Motility positif (+) karena bakteri menggunakan asam amino triptofan sebagai sumber karbon hal ini ditandai dengan munculnya awan pada media.

Pada media Methyl Red (MR) positif (+) karena bakteri mampu untuk mengoksidasi glukosa dengan memproduksi asam dengan konsentrasi tinggi sebagai hasil akhirnya hal ini ditandai dengan munculnya cincin merah pada media setelah ditambahkan reagen methyl red. Pada media Voges Proskauer (VP) negatif (-) yakni tidak terbentuk cincin ungu setelah ditambahkan reagen alfanaftol dan $\mathrm{KOH}$ karena bakteri tidak menggunakan acetyl-methylcarbinol (asetoin) sebagai sumber pemuka.

Pada media gula-gula yakni glukosa (+), sukrosa (+) dan laktosa (+) terdapat berwarna kuning karena bakteri menghasilkan gas pada tabung durham. Sehingga dapat disimpulkan dari 5 sampel yang telah di uji dinyatakan seluruh sampel mengandung Salmonella sp.

Menurut Riga et al. (2015) ada beberapa macam bakteri yang bersifat patogen dan masuk dalam anggota famili Enterobacteriaceae, diantaranya genus Enterobacter, $S$ erratia, Escherichia, Proteus, Salmonella, Shigella, dan Klebsiella. Menurut penelitian yang telah dilakukan oleh Agustin, Y.V. et al (2019), bahwa didapatkan sekitar 20\% dari 10 sampel spons cuci piring yaitu 
Escherichia coli. Jadi kemungkinan kontaminasi Salmonella $s p$ pada spons cuci piring dapat terjadi dikarenakan Salmonella $s p$ masuk dalam anggota genus enterobacter yang penyebarannya lewat makanan.

Pada penelitian ini pertumbuhan Salmonella sp pada spons cuci piring dapat didukung oleh beberapa faktor diantaranya air rendaman yang digunakan merupakan air mentah serta sisa-sisa makanan pada spons cuci piring. KESIMPULAN

Berdasarkan hasil penelitian pada identifikasi Salmonella sp pada spons cuci piring bekas yang direndam selama 3 hari ditemukan adanya bakteri Salmonella $s p$.

\section{DAFTAR PUSTAKA}

Agustin, Y.V., Ilsan, N.A., Inggraini, M. 2019. Bakteri Patogen Dalam Spons Cuci Piring Pada Penjual Makanan Di Pasar Margahayu, Bekasi Timur. Jurnal Mitra Kesehatan. 2 (1): 15-20.

Jannah, R. 2018. Hubungan Hiegene Spons Pencuci Piring Pedagang
Kaki Lima (PKL) Dengan Jumlah Bakteri Total Dan Cemaran Escherichia Coli. Skripsi Program Studi DIV Analis Kesehatan Fakultas Kesehatan Universitas Nahdlatul Ulama Surabaya.

Kalem, R.S., Sulistyowati, E. 2019.

Kesadaran Hukum Konsumen

Terkait Pencantuman Label Cara

Penggunaan Pada Spons Cuci

Piring. Jurnal Hukum. 6 (1). Surabaya.

Saleh, S.R. 2020. Studi Literatur Identifikasi Escherichia Coli Pada Siomay. KTI Prodi D-III

Supriani, 2019. Identifikasi Salmonella $s p$ Pada TST (Teh Susu Telur) Yang Diperjualbelikan Di Jalan Williem Iskandar Medan. KTI Politeknik Kesehatan Kemenkes Medan Jurusan Analis Kesehatan. Medan.

Tumerlap, 2011. Kondisi Bakteriologik Peralatan Makan Di Rumah Makan Jombang Tikala Manado. Jurnal Kesehatan Lingkugan. Vol. 1 No. 1. Manado. 